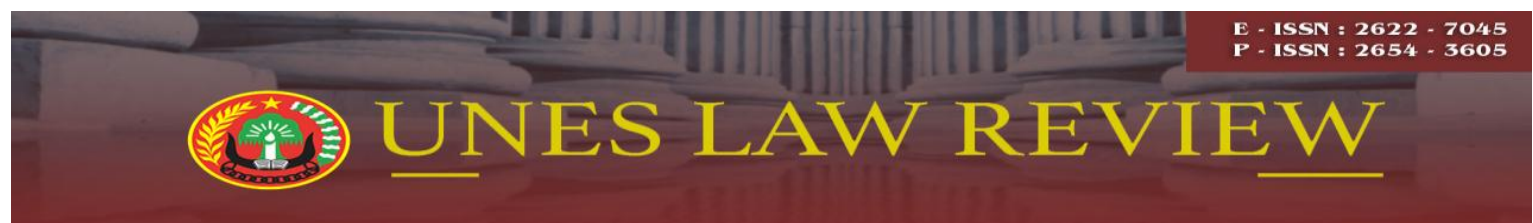

Email: uneslawreview@gmail.com

Online: http://review-unes.com/index.php/law

Volume 2, Issue 4, Juni 2020

\title{
PERLINDUNGAN KONSUMEN ATAS KERUGIAN PELAYANAN DAN KENAIKAN BIAYA INDIHOME DI KOTA PADANG
}

\author{
Vony Febryan \\ Program Magister Ilmu Hukum, Universitas Ekasakti, Padang, Indonesia \\ Email: febryanivony17@gmail.com
}

\begin{abstract}
The problems discussed:How are consumers protection for service losses and increased indihome costs in padang city? How are Dispute resolution of consumer in service losses and increased of indihome costs?This research is Descriptive analytical, normative juridical and empirical juridical approach conducted in Padang city By using interview consumers, and manager of customer care (PT) Telecommunications Indonesia Regional of Padang. The results of this researchConsumer protection for the loss of service and an increase in the cost of Indihome in the city of Padang that the consumer has not fully obtained legal protection, because PT. Telkom only cancel Internet content Catchplay service To prevent future charges from appearing, An Indihome service fee increases that the charge is still charged to the consumer. In the absence of compensation from PT. Telkom, consumers are Highly harmed.Dispute resolution of consumer Loss of service and increase of indihome costs is the consumer only signed a statement letter containing the release of PT. Telkom City of Padang demands,PT.TELKOM does not conduct deliberations in accordance with the provisions Indihome Contract subscription regarding the settlement of disputes between PT. Kota Padang Telkom with the customer must be resolved by means of deliberation.
\end{abstract}

Kata Kunci: Perlindungan Konsumen, Kerugian Pelayanan, Kenaikan Biaya, Indihome

\section{PENDAHULUAN}

Pengaruh globalisasi dan perkembangan teknologi yang sangat pesat telah mengakibatkan perubahan yang mendasar dalam penyelenggaraan dan cara pandangan terhadap pembangunan. Sejalan dengan kemajuan pembangunan tersebut maka penyelenggaraan jasa telekomunikasi mempunyai arti stategis dalam upaya memperkokok persatuan dan kesatuan bangsa, memperlancar kegiatan pemerintahan, mendukung terciptanya tujuan pemerataan pembangunan dan hasil-hasilnya, serta meningkatkan hubungan antara bangsa (Danrivanto Budhijanto, 2010:43)

PT. Telekomunikasi Indonesia (persero). Tbk, disingkat PT Telkom, merupakan Badan Usaha Milik Negara (BUMN), didirikan berdasarkan Peraturan Pemerintah Nomor 
25 Tahun 1991 yang sebelumnya bernama Perusahaan Umum Telekomunikasi (Perumtel), adalah perusahan yang memegang izin dari pemerintah untuk melaksanakan kegiatan usaha bidang penyelenggara telekomunkasi di Indonesia.

Salah satu usaha PT.Telekomunikasi Indonesia Kota Padang hanya menyediakan layanan jasa alat telekomunikasi berupa telepon rumah. Seiring dengan perkembangan zaman serta kebutuhan masyarakat dalam mengakses informasi, munculah beberapa jenis teknologi telekomunikasi yang membuat masyarakat berubah menjadi lebih maju dengan adanya internet.

Berkembangnya teknologi informasi, PT.Telekomunikasi Indonesia Kota Padang menyediakan produk jasa layanan internet berlangganan salah satunya adalah indihome, produk ini tersedia untuk koneksi internet dikalangan bisnis bahkan meluas sampai kerumah-rumah, sehingga membuat banyak masyarakat yang menggunakan layanan internet dengan cara berlangganan untuk dipasang dirumah.

Perlindungan Konsumen seharusnya perlu ditingkatkan sehingga hak-hak konsumen dapat ditegakkan.Namun, perlu pula diperhatikan dalam hal memberikan perlindungan kepada konsumen tidak juga mematikan usaha yang dijalankan pelaku usaha. Oleh karena itu sangat penting untuk ditegakkan peraturan perlindungan konsumen yang berlaku di Indonesia seiring dengan upaya meningkatkan dan menumbuhkan kesadaran pelaku usaha mengenai pentingnya perlindungan konsumen, sehingga pelaku usaha timbul sikap yang jujur dan bertanggungjawab dalam berusaha.

BerdasarkanUraian diatas, maka penulis tertarik untuk mengetahui dan menganalisis "Perlindungan Konsumen Atas Kerugian Pelayanan dan Kenaikan Biaya Indihome Di Kota Padang”.

\section{METODE PENELITIAN}

Untuk menjawab pemasalahan seperti yang telah di uraikan, Penelitian atau research adalah upaya menemukan infromasi kembali dengan cermat, hati-hati, telaten dan bersungguh-sungguh makna menemukan adalah kegiatan mencari sesuatu yang sebenarnya telah ada namun belumd iformulasikan secara sistematis (Ade Saptomo, 2007:28)

Penelitian ini menggunakan pendekatan yuridis normatif (normative legal research), dan pendekatan yuridis empiris (empirical legal research). Disebut demikian 
karena penelitian ini merupakan penelitian kepustakaan atau studi dokumen yang dilakukan ditujukan hanya pada peraturan-perturan yang tertulis atau bahan hukum yg lain (Bambang waluyo, 1996:13).

Pendekatan normatif adalah dilakukan pengumpulan dan penyajian data dengan mempelajari peraturan-peraturan secara kepustakaan mengenai perlindugan konsumen atas kerugian pelayanan dan kenaikan biaya Indihome.

Teknik Pengumpulan data yang digunakan data yang digunakan dalam penelitian ini yaitu Data sekunder melalui studi kepustakaan dengan cara mengumpulkan, menginventarisasikan dari berbagai bahan hukum, literatul, dan dokumen yang mendukung objek penelitian.Data Primer dalam penelitian ini melalukan studi lapangan berupa wawancara para pihak yang terkait dalam penelitian ini yaitu : Manager Customer Care (PT.Telekomunikasi Indonesia Kota Padang), Kepala Badan Penyelesaian Sengketa Konsumen (BPSK) kota Padang,Konsumen yang dirugikan mengenai biaya Indihome.

Analisis yuridis adalah mengumpulkan hukum dan dasar lainnya yang relevan untuk kemudian mengambil kesimpulan sebagai jalan keluar atau jawaban atas permasalahan (Bahder Johan Nasution, 2008:83-84). Data Primer dan Data Sekunder yang telah terkumpul di analisa yuridis secara kualitatif serta disajikan salam bentuk deskriptif.

\section{HASIL PENELITIAN DAN PEMBAHASAN}

\section{Hasil Penelitian}

Hasil Penelitian Pelayanan Penggunaan Jasa Layanan Internet Oleh PT Telkom Indonesia (Persero) Tbk (Telkom) adalah Badan Usaha Milik Negara (BUMN) yang bergerak di bidang jasa layanan teknologi informasi dan komunikasi (TIK) dan jaringan telekomunikasi di Indonesia, beserta seluruh anak perusahaan dan affiliasinya. Perusahaan ini memiliki visi "Be the King of Digital in the Region" adalahmenjadi raja di Digital di daerah. Misi PT. Telkom Indonesia adalah "Lead Indonesian Digital Innovation and Globalization” adalah Memimpin Inovasi Digital Indonesia dan Globalisasi.

PT.Telkom Memiliki Tujuan Strategis yaitu : Strategic Objectives Sebagai Indonesia powerhouse company yang telah memiliki footprint bisnis internasional, TelkomGroup memiliki strategic objectives sebagai berikut : "Top 10 Market Capitalization Telco in Asia-Pacific by 2020 and maintain its stronghold position" yaitu 
Telkom Indonesia sedang bertransformasi menuju 10 besar perusahaan telekomunikasi digital berkapitalisasi terbesar di Asia Pacific pada tahun 2020.

\section{Gambar 1}

Profil Regional 1 Wilayah Sumatera Barat

\section{STRUKTUR ORGANISASI WITEL SUMBAR}

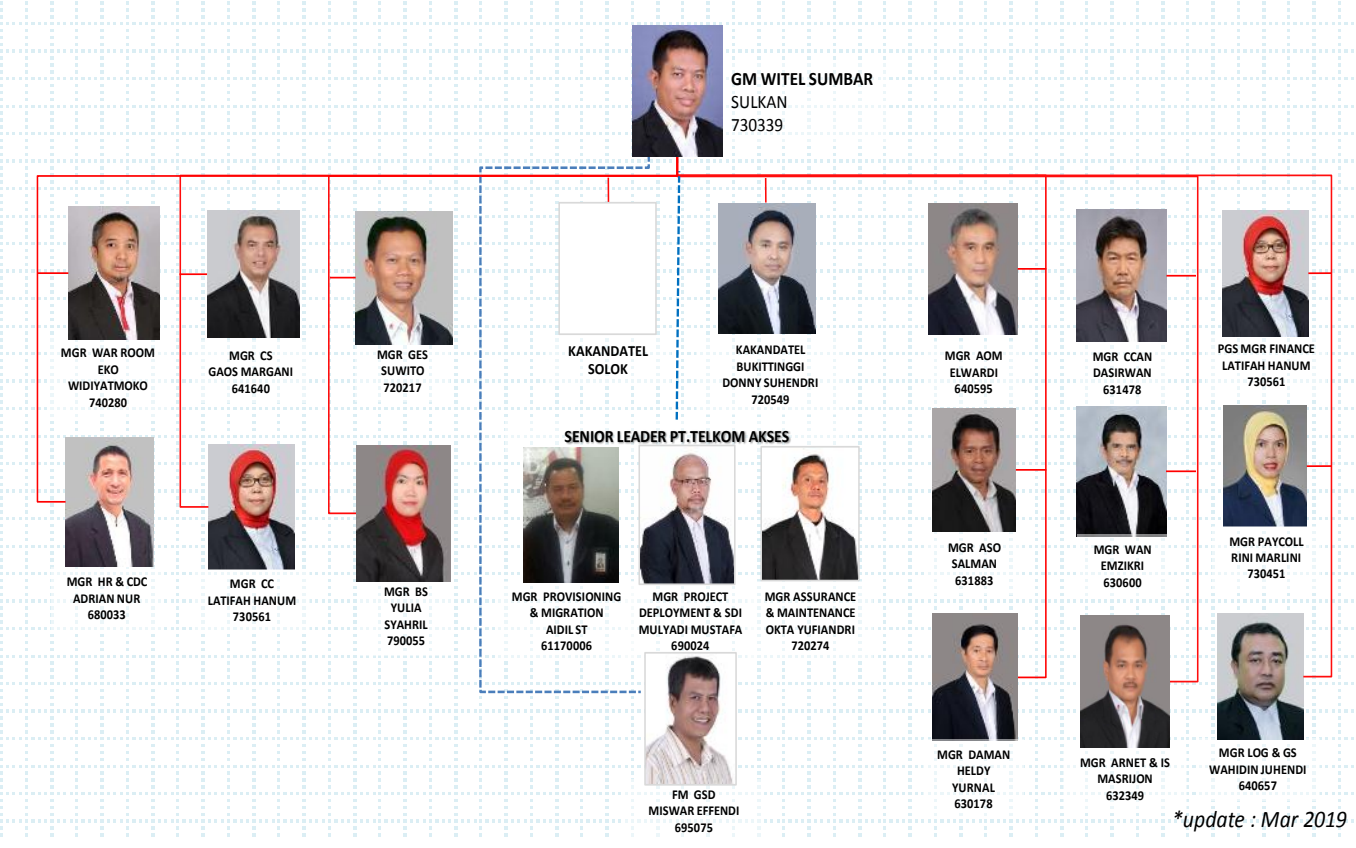

Berdasarkan Hasil wawancara kepada ibu Hanum selaku manager customer care berupa stuktur organisasi PT.Telkom Kota Padang.

Kegiatan usaha PT. Telekomunikasi Indonesia, Tbk bertumbuh dan berkembang seiring dengan perkembangan teknologi, informasi dan digital. Namun masih dalam koridor industri telekomunikasi dan informasi serta kegiatan usaha PT. Telkom ini berdasarkan anggaran dasar perusahaan yang mengacu pada versi terakhir anggaran dasar PT. Telkom Nomor 20 Tanggal 23 Mei 2015 yang menyebutkan bahwa maksud dan tujuan kegiatan usaha ini adalah menyelenggarakan jaringan dan jasa telekomunikasi, informatika serta optimalisasi sumber daya perseroan. Sejalan dengan maksud dan tujuan, maka kegiatan usaha PT. Telkom mencakup :

1. Usaha Utama

a. Merencanakan, membangun, menyediakan, mengembangkan, mengoperasikan, memasarkan, menjual atau menyewakan dan memelihara jaringan telekomunikasi dan informasi dalam arti luas dengan memperhatikan ketentuan-ketentuan peraruran dan perundang-undangan yang berlaku. 
b. Merencanakan, mengembangkan, menyediakan, memasarkan atau menjual dan meningkatkan layanan jasa telekomunikasi dan informatika dalam arti luas dengan memperhatikan ketentuan peraturan dan perundang-undangan yang berlaku.

c. Melakukan investasi termasuk penyertaan modal pada perusahaan lainnya sejalan dengan dan untuk mencapai maksud dan tujuan Perseroan.

2. Usaha Penunjang

a. Menyediakan jasa transaksi pembayaran dan pengiriman uang melalui jaringan telekomunikasi dan informatika.

b. Menjalankan kegiatan dan usaha lain dalam rangka optimalisasi sumber daya yang dimiliki Telkom, salah satunya pemanfaatan aktiva (harta) tetap dan aktiva bergerak, fasilitas sistem informasi, pendidikan dan pelatihan dan fasilitas pemelihara dan perbaikan.

c. Dalam hal ini, bekerja sama dengan pihak lain dalam rangka mengoptimalkan resources, seperti sumber daya informatika, komunikasi atau teknologi yang dimiliki oleh pihak lain yang memiliki pandangan atau sejalan dengan maksud dan tujuan PT. Telkom.

Indihome merupakan layanan digital terdepan menggunakan teknologi serat optik yang menawarkan layanan Triple Play yang terdiri dari Internet Fiber (Internet Cepat), Telepon Rumah (Fixed Phone) dan TV Interaktif (UseeTV). Indihome juga menawarkan layanan Dual Play yang terdiri dari Internet Fiber (Internet Cepat) dan Telepon Rumah (Fixed Phone). Indihome juga dilengkapi dengan beragam layanan tambahan (Add-On) yang bisa dipilih sesuai kebutuhan dan keinginan Pelanggan seperti Telepon Mania, Wifi.id Seamless, Trend Micro Antivirus, Indihome View (online surveillance camera) dan masih banyak lagi.

Terkait Prosedur pemasangan Indihome ini sendiri terlabih dahulu dilakukan adalah pendaftaran, kemudian biaya pemasangan, pemasangan, dan yang terakhir adalah pembayaran. Pendaftaran dibagi menjadi dua yaitu pendaftaran secara online dan Secara Offline.

\section{Pembahasan}

\section{Perlindungan Konsumen Atas Kerugian Pelayanan dan Kenaikan Biaya Indihomedi Kota Padang}

Perlindungan konsumen bagi pelanggan indihome Kota Padang bahwa didalam kontrak belangganan muncul hak dan kewajiban masing-masing para pihak. Kewajiban PT.Telkom Kota Padang adalah sebagai berikut :

1. Menyediakan layanan Indihome di alamat Pelanggan atas permintaan Pelanggan yang memenuhi ketentuan teknis Telkom. 
2. Memberikan pelayanan yang baik dan transparan terkait layanan Indihome kepada Pelanggan.

3. Memberikan informasi mengenai spesifikasi teknis, sifat-sifat dan karakteristik umum layanan Indihome yang disediakan Telkom, melalui brosur, leaflet, Plasa Telkom, 147 atau media lainnya.

4. Memberikan jaminan tingkat layanan (Service Level Guarantee) Indihome sesuai dengan ketentuan Telkom.

5. Memberikan kompensasi kepada Pelanggan bila jaminan tingkat layanan (Service Level Guarantee) Indihome tidak terpenuhi atau terbukti ada kesalahan tagihan.

6. Menindak lanjuti laporan Pelanggan jika sambungan layanan Indihome di alamat Pelanggan mengalami gangguan/kerusakan.

7. Menindak lanjuti laporan Pelanggan atas setiap pemindah-tanganan hak tanggung jawab dan/atau kewajiban Pelanggan terkait layanan Indihome kepada pihak lain.

8. Menindak lanjuti permintaan Pelanggan untuk berhenti berlangganan layanan Indihome sementara atau memutuskan kontrak berlangganan.

Didalam Pasal 7 Undang-Undang Perlindungan Konsumen Nomor 8 Tahun 1999, Kewajiban Pelaku Usaha yaitu:

1. beritikad baik dalam melakukan kegiatan usahanya;

2. memberiksn informasi yang benar, jelas dan jujur mengenai kondisi dan jaminan barang dan/atau jasa serta memberi penjelelasan penggunaan, perbaikan dan pemeliharaan;

3. memperlakukan atau melayani konsumen secara benar dan jujur serta tidak diskriminatif;

4. menjamin mutu barang dan/atau jasa yang diproduksi dan/atau diperdagangkan berdasarkan ketentuan standar mutu barang dan/atau jasa yang berlaku;

5. memberi kesempatan kepada konsumen untuk menguji, dan/atau mecoba barang dan/atau jasa tertentu serta memberi jaminan dan/atau garansi atas barang yang dibuat dan/atau jasa yang diperdagangkan;

6. memberi kompensasi, ganti rugi dan/atau penggantian atas kerugian akibat penggunaan, pemakaian dan pemanfaatan barang dan/atau jasa yang diperdagangkan;

7. memberi kompensasi, ganti rugi dan/atau penggantian apabila barang dan/atau jasa yang diterima atau dimanfaatkan tidak sesuai dengan perjanjian.

Menurut Penulis, Kewajiban PT. Telkom Kota Padang belum sesuai dengan ketentuan Pasal 7 huruf a, b, c, f dan g Undang-Undang Nomor 8 Tahun 1999 Tentang Perlindungan Konsumen. Kewajiban PT. Telkom kota padang bahwa dimana pelaku usaha tidak memberikan infromasi yang benar dan jelas, tidak beritikad baik dalam menjalankan usahanya dan pelaku usaha tidak memberikan konsumen kompensasi atas kenaikan biaya paket indihome. 
Dalam Pasal 10 huruf c undang-Undang Perlindungan Konsumen Pelaku usaha dalam menawarkan barang dan/atau jasa yang ditujukan untuk diperdagangkan dilarang menawarkan, mempromosikan, mengiklankan atau membuat pernyataan yang tidak benar atau menyesatkan mengenai kondisi, tanggungan, jaminan, hak atau ganti rugi atas suatu barang dan/atau jasa.

Informasi mengenai hak atau ganti rugi PT.Telkom Kota Padang tidak menjalakan sesuai dengan ketentuan yang berlaku. Berdasarkan hasil wawancara dengan Ibu Hanum selaku Manager customer care PT.Telkom Kota Padang, perlindungan hukum secara represif yang diberikan PT. Telkom kepada konsumen adalah :

1. Melalui pendekatan persuasif (musyawarah)

Dimana melalui pendekatan ini, berdasarkan keluhan atau komplain yang disampaikan oleh konsumen kepada Telkom dalam bentuk laporan ke 147, melalui surat, ataupun melapor langsung ke Plasa Telkom, setelah itu pihak konsumen dipertemukan dengan pihak dari PT. Telkom, kemudian pihak konsumen dapat menceritakan segala keluhan yang dialaminya, dan pihak PT. Telkom Kota Padang memberikan penjelasan mengenai penyebab mengapa terjadinya kenaikan biaya indihome yang dapat merugikan konsumen tersebut. Dengan kata lain, dilakukan musyawarah untuk membicarakan penyelesaian masalah yang dihadapi.

Dalam hal menyampaikan keluhan, Telkom telah menyediakan layanan untuk mempermudah konsumen dalam menyampaikan keluhan atau melaporkan gangguan yang dialami melalui 147, facebook : Telkompromo atau Telkomcare, Twitter : @telkompromo atau @telkomcare dan aplikasi MyIndihome.

2. Memberikan kompensasi/ganti rugi

Kompensasi diberikan kepada konsumen apabila konsumen menyatakan ia merasa dirugikan akibat terjadinya kenaikan biaya indihome tersebut, dan dapat terbukti pula bahwa konsumen tersebut memang mengalami kenaikan biaya atau tarif dan terbukti bahwa tersebut karena kelalaian PT.Telkom Kota Padang, bukan karena kelalaian atau kesalahan konsumen sendiri. Dimana kompensasi ini pun bukan berupa uang, melainkan benefit, misalnya gratis berlangganan di bulan berikutnya.

Apabila konsumen tidak puas dengan hasil musyawarah maka kasus ini dapat dilanjutkan ke Pengadilan Negeri atau BPSK (Badan Penyelesaian Sengketa Konsumen), dimana para pihak yaitu PT. Telkom Kota Padang dan Konsumen Indihome harus dapat menerima putusan dari pihak yang berwenang, apabila diputuskan bahwa PT. Telkom harus memberikan ganti rugi, maka PT. Telkom harus memberikan ganti rugi kepada konsumen Indihome tersebut.

\section{Penyelesaian Sengketa Konsumen dalam Kerugian Pelayanan dan Kenaikan Biaya Indihome Di Kota Padang}

Hubungan antara konsumen Indihome dengan PT. Telkom Kota Padang tentunya didasarkan kepada hak dan kewajiban para pihak. Salah satu kewajiban Konsumen 
Indihome ialah membayar biaya jasa internet yang digunakan setiap bulannya. PT. Telkom Kota Padang wajib memenuhi hak - hak konsumen Indihome termasuk mengenai informasi tarif atau harga jika terajdi kenaikan. Tetapi tidak jarang pihak PT. Telkom tidak memenuhi kewajibannya disebabkan karena kelalaiannya maupun karena diluar kendali PT. Telkom itu sendiri.

Sering kali terdengar keluhan konsumen Indihome dari mulut ke mulut maupun melalui media massa mengenai kelalaian PT. Telkom dikarenakan informasi yang tidak akurat mengenai produk layanan indihome. Namun, konsumen tersebut tidak hanya "mengeluh", sebagian ada yang langsung melaporkan keluhannya ke Plasa Telkom, melalui call center 147, atau bahkan menyurati pihak Telkom.

Apabila dilihat dari Ketentuan berlangganan Indihome tentang Penyelesaian Perselisihan, bahwa :

1. Perselisihan yang menyangkut pelaksanaan dan/atau penafsiran atas kontrak berlangganan diselesaikan bersama oleh Telkom dan pelanggan secara musyawarah.

2. Apabila penyelesaian secara musyawarah berdasarkan ketentuan dalam kontrak berlangganan tidak tercapai maka Telkom dan pelanggan sepakat menyerahkan penyelesaiannya kepada Pengadilan Negeri (PN)/Badan Penyelesaian Sengketa Konsumen (BPSK) dengan domisili hukum dilokasi kantor Telkom setempat.

Penyelesaian sengketa konsumen dalam kerugian pelayanan dan kenaikan biaya indihome yaitu konsumen hanya menandatangani surat pernyataan yang berisi membebaskan PT.Telkom Kota Padang dari tuntutan. PT.Telkom selaku pelaku usaha tidak menjalankan musywarah sesuai ketentuan kontrak berlangganan indihome mengenai penyelesaian perselisihan antara PT.Telkom Kota Padang dengan Pelanggan yang seharusnya diselesaikan dengan cara musyawarah.

Namun halnya surat pernyataan itu bukanlah musyawarah, karena ketika melakukan musyawarah akan ditanda tangani kedua belah pihak dan ditemukan kesepakatan bersama agar kedua belah pihak mendapatkan keadilan itu sendiri. Di dalam kontak diterapkan musyawarah namun didalam prakteknya dilapangan musyawarah tidak diterapkan konsumen selalu dalam posisi lemah.

Dalam Ketentuan Pasal 45 Undang-Undang Perlindungan Konsumen 
(1) Setiap konsumen yang dirugikan dapat menggugat pelaku usaha melalui lembaga yang bertugasmenyelesaikan sengketa antara konsumen dan pelaku usaha atau melalui peradilan yang beradadi lingkungan peradilan umum.

(2) Penyelesaian sengketa konsumen dapat ditempuh melalui pengadilan atau diluar pengadilan berdasarkan pilihan sukarela para pihak yang bersengketa.

(3) Penyelesaian sengketa di luar pengadilan sebagaimana dimaksud pada ayat (2) tidak menghilangkan tanggung jawab pidana sebagaimana diatur dalam Undangundang.

(4) Apabila telah dipilih upaya penyelesaian sengketa konsumen di luar pengadilan, gugatan melalui pengadilan hanya dapat ditempuh apabila upaya tersebut dinyatakan tidak berhasil oleh salah satu pihak atau oleh pihak yang bersengketa.

Berdasarkan Ketentuan Kontrak Belangganan indihome Penyelesaian Sengketa, PT.Telkom Kota padang yang mengatakan tentang cara penyelesaian klaim keberatan atas tagihan tentang tata cara pengajuan tuntutan dan jalur penyelesaian sengketa dan yang menyebutkan jalur pertama yang ditempuh dalam penyelesaian sengketa adalah musyawarah dan apabila gagal dapat ditempuh melalui jalur pengadilan negeri. Dalam ketentuan Pasal 48 undang-undang perlindungan konsumen "Penyelesaian sengketa konsumen melalui pengadilan mengacu pada ketentuan tentang peradilan umum yang berlaku dengan memperhatikan ketentuan dalam Pasal 45.

Dalam penyelesaian sengketa konsumen antara pelanggan layanan Indihome dengan PT. Telkom Kota Padangapabila ditetapkan suatu ganti rugi yang harus dibayar PT Telekm, ganti rugi tersebut haruslah berbentuk ganti rugi pengembalian uang atas kesalahan penghitungan biaya tagihan pemakaian yang telah ditagih sebelumnya.

\section{PENUTUP}

Perlindungan konsumen atas kerugian pelayanan dan kenaikan biaya indihome yaitu bahwa konsumen belum sepenuhnya mendapatkan perlindungan hukum, karena PT.Telkom Kota Padang hanya membatalkan layanan internet content catchplay agar tagihan selanjutnya tidak muncul, tagihan sebelumnya yang terjadi kenaikan biaya produk layanan indihome bahwa tagihan tersebut tetap dibebankan kepada konsumen. Dengan tidak diberikannya kompensasi dari PT.Telkom Kota Padang konsumen sangat dirugikan.

Penyelesaian sengketa konsumen dalam kerugian pelayanan dan kenaikan biaya indihome yaitu konsumen hanya menandatangani surat pernyataan yang berisi membebaskan PT.Telkom Kota Padang dari tuntutan. PT.Telkom tidak menjalankan 
musyawarah sesuai ketentuan kontrak berlangganan indihome mengenai penyelesaian perselisihan antara PT.Telkom Kota Padang dengan Pelanggan yang seharusnya diselesaikan dengan cara musyawarah.

\section{DAFTAR PUSTAKA}

\section{Buku Teks:}

Ade Saptomo,Pokok-pokok Metedologi Penelitian Hukum, Unesa University Press. Surabaya. 2007

Bahder Johan Nasution, Metode Penelitian Ilmu Hukum, Mandar Maju. Bandung. 2008. hlm.83-84

Bambang Waluyo, 1996. Metode Penelitian Hukum, Sinar Grafik, Jakarta

DanrivantoBudhijanto, HukumTelekomunikasi, Penyiaran, \& Teknologi Informasi, Regulasi dan Konvergensi, PT.Refika Aditama. Bandung. 2010

\section{Peraturan Undang-Undang :}

Undang-Undang Dasar Negara Republik Indonesia Tahun 1945;

Kitab Undang-Undang Hukum Perdata;

Undang-Undang Nomor 8 Tahun 1999 tentang Perlindungan Konsumen;

Undang-Undang Nomor 5 Tahun 1999 tentang Larangan Praktek Monopoli dan Persaingan Usaha Tidak Sehat;

Undang-Undang Nomor 36 Tahun 1999 tentang Telekomunikasi;

Undang-Undang Nomor 30 Tahun 1999 tentang Arbitrase dan Alternatif Penyelesaian Sengketa;

Undang-Undang Nomor 40 Tahun 2007 tentang Perseroan Terbatas;

Undang-Undang Nomor 11 Tahun 2008 tentang Informasi dan Transaksi Elektronik;

Peraturan Pemerintah Nomor 25 Tahun 1991 tentang Perusahaan Umum Telekomunikasi (Perumtel);

Peraturan Pemerintah Nomor 58 Tahun 2001 tentang Pembinaan Pengawasan dan Penyelenggaraan Perlindungan Konsumen

Surat Edaran Dirjen Perdagangan Dalam Negeri Nomor 235/DJPDN/VII/2001 Tentang Penangan pengaduan konsumen yang ditujukan kepada Seluruh dinas Indag Prop/Kab/Kota

Surat Edaran Direktur Jenderal Perdagangan Dalam Negeri Nomor 795 /DJPDN/SE/12/2005 tentang Pedoman Pelayanan Pengaduan Konsumen 